\title{
Effect of highly reflective roofing sheet on building thermal loads for a school in Osaka
}

\author{
Jihui Yuan ${ }^{1,2, a}$, Kazuo Emura ${ }^{1}$ and Craig Farnham ${ }^{1}$ \\ ${ }^{1}$ Dept. of Housing and Environmental Design, Graduate School of Human Life Science, Osaka City University, \\ Osaka 558-8585, Japan \\ ${ }^{2}$ School of Environmental Science and Engineering, Huazhong University of Science and Technology, Wuhan, \\ Hubei 430074, China
}

\begin{abstract}
Currently, urban heat island (UHI) phenomenon and building energy consumptions are becoming serious. Strategies to mitigate UHI and reduce building energy consumptions are implemented worldwide. In Japan, as an effective means of mitigating UHI and saving energy of buildings, highly reflective (HR) and green roofs are increasingly used. In order to evaluate the effect of roofs with high reflection and thermal insulation on the energy conservation of buildings, we investigated the roof solar reflectivity of the subject school in Osaka, in which the HR roofing sheet was installed on the roof from 2010. Thermal loads, including cooling and heating loads of the top floor of school, were calculated using the thermal load calculation software, New HASP/ACLD- $\beta$. Comparing the thermal loads after HR roofing sheet installation to previous, the annual thermal load decreased about $25 \mathrm{MJ} / \mathrm{m}^{2}$-year and the cooling load decreased about $112 \mathrm{MJ} / \mathrm{m}^{2}$-year. However, the heating load increased about 87 $\mathrm{MJ} / \mathrm{m}^{2}$-year in winter. To minimize the annual thermal load, thermal insulation of the roof was also considered be used together with HR roofing sheet in this study. The results showed that the combination of HR roofing sheet and high thermal insulation is more effective to reduce the annual thermal load.
\end{abstract}

\section{Introduction}

Urban heat island (UHI) is a well-documented climatic change phenomenon [1]. UHI intensity in hot climates may rise up $10^{\circ} \mathrm{C}[2,3]$, resulting in increased discomfort, higher pollution levels while it has a serious impact on the cooling energy consumption of buildings [4]. Important research has been carried out to document its influence on the urban climate [5,6]. As the same UHI phenomenon has become serious, the energy consumption in buildings is also increasing rapidly. Among strategies of mitigating UHI and reducing energy consumption of buildings, highly reflective (HR) materials [7,8] applied to building roofs or retro-reflective (RR) materials [9-11] used for building facades have been researched globally. HR or RR building envelope materials can reduce the cooling load in the summer due to their high solar reflectivity. However, the HR and RR envelopes can also increase the heating load in the winter [12].

In three major cities (Tokyo, Nagoya, Osaka) of Japan, under global warming in progress at the rapid rate, the temperature of Osaka rises $2.1^{\circ} \mathrm{C}$ in 100 years which is higher than the national average

\footnotetext{
${ }^{a}$ Corresponding author : yuanjihui@ hotmail.co.jp
} 
temperature $1.0^{\circ} \mathrm{C}$, this difference $1.1^{\circ} \mathrm{C}$ is thought to be due to heat island effect [13]. The global contribution from buildings towards energy consumption, both residential and commercial, has steadily increased to between $20 \%$ and $40 \%$ in developed countries, and has exceeded the other major sectors: industrial and transportation [14]. Buildings in the urban area are a major contributor to the UHI phenomenon. Focusing on the anthropogenic heat emissions, a study showed that exhaust heat from buildings in Japan accounted for approximately half of the anthropogenic heat in the city [15]. Thus, to reduce energy consumption in buildings plays an important role in countering the UHI effect. Many studies to subject the UHI effect have also been implemented widely in Japan [16-19].

In order to mitigate UHI effect and reduce energy consumption of buildings, HR roofing sheets were installed on the roofs of 70 schools in Osaka, Japan from 2010. The solar reflectivity of HR roofing sheets installed on roofs was investigated [20]. In order to evaluate the effect of HR roofing sheet on the energy conservation of buildings, this study aims to calculate and compare the thermal load of building before and after HR roofing sheet installation on the subject school roof. Additionally, to minimize the thermal load of buildings, it is necessary to consider applying appropriate thermal insulation together with the HR roofing sheet to the roof in this study.

\section{Subject school and HR roofing sheet}

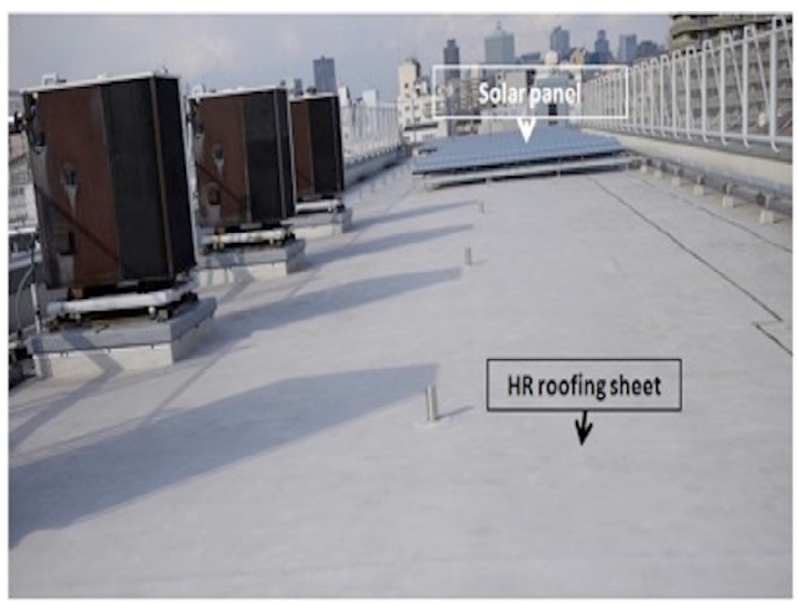

Figure 1. The roof appearance of subject school coated with HR roofing sheet.

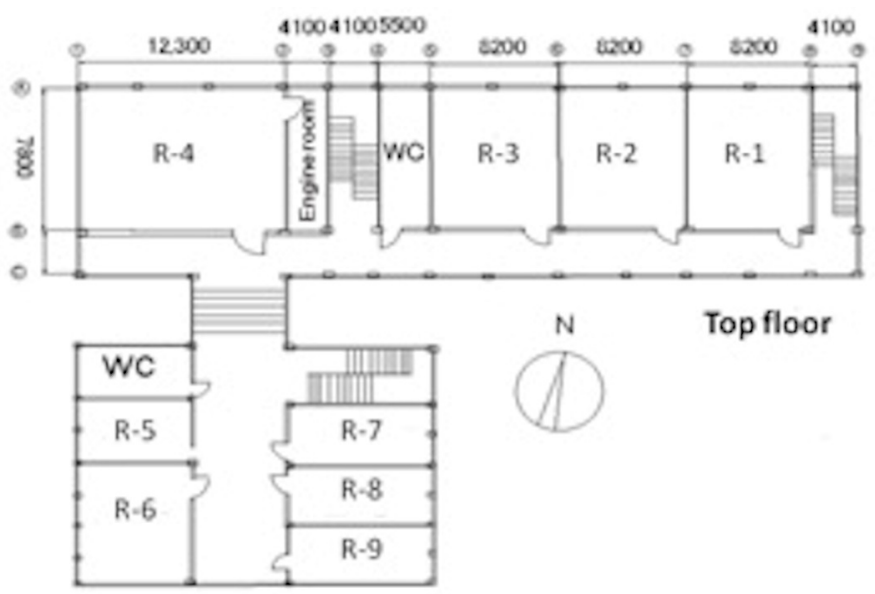

Figure 2. Ground plan of the top floor of subject school with a floor area of about $683 \mathrm{~m}^{2}$. 
The roof appearance of the subject school covered with HR roofing sheet is shown in Figure 1 . The ground plan of the top floor (the 4th floor) of the school building with a floor area of about $683 \mathrm{~m}^{2}$ is shown in Figure 2. Structures of the roof, floor, exterior wall and interior wall are shown in Table 1.

The HR roofing sheet has high solar reflectivity in the near-infrared (NIR) range regardless of the solar reflectivity in the visible (VIS) range.

According to the previous research [20], the solar reflectivity of HR roofing sheet in visible range $(400-780 \mathrm{~nm})$ was about 0.5 , about 0.58 in near-infrared range $(780-1700 \mathrm{~nm})$ and about 0.54 in all wavelengths (400-1700 $\mathrm{nm}$ ) by the investigation of previous study.

Table 1. Structures of roof, floor, exterior wall and interior wall of school buildings.

\begin{tabular}{l|l|l}
\hline & \multicolumn{1}{|c}{$\begin{array}{c}\text { Case A: before construction of HR } \\
\text { roofing sheet }\end{array}$} & \multicolumn{1}{c}{$\begin{array}{c}\text { Case B: after construction of HR } \\
\text { roofing sheet }\end{array}$} \\
\hline Roof & $\begin{array}{l}\text { In order from indoor to outdoor: } \\
\text { Rock wool }(12 \mathrm{~mm})+\text { Gypsum board }(9 \\
\mathrm{mm})+ \text { Hollow layer + Ordinary concrete } \\
(150 \mathrm{~mm})+\text { mortar }(15 \mathrm{~mm})+\text { Asphalt } \\
(10 \mathrm{~mm})+\text { Light concrete }(60 \mathrm{~mm})\end{array}$ & $\begin{array}{l}\text { In order from indoor to outdoor: } \\
\text { A + HR roofing sheet }(3 \mathrm{~mm})\end{array}$ \\
\hline Floor & $\begin{array}{l}\text { In order from top to bottom: } \\
\text { Plastic tile }(3 \mathrm{~mm})+\text { Mortar }(15 \mathrm{~mm})+\text { Ordinary concrete }(150 \mathrm{~mm})+\text { Hollow layer }+\end{array}$ \\
\hline Exterior wall & $\underline{\text { In order from indoor to outdoor: }}$ \\
\hline Interior wall & Mortar $(20 \mathrm{~mm})+$ Ordinary concrete $(150 \mathrm{~mm})+$ Mortar $(20 \mathrm{~mm})+$ Tile $(8 \mathrm{~mm})$ \\
\hline
\end{tabular}

\section{Thermal load calculations}

Table 2. Conditions of the thermal load calculations.

\begin{tabular}{|c|c|c|c|c|}
\hline \multirow{2}{*}{ External condition } & \multicolumn{4}{|c|}{ Standard weather data: Expanded AMeDAS Weather Data of Japan } \\
\hline & \multicolumn{4}{|c|}{$\begin{array}{l}\text { Location: Osaka, Japan } \\
\end{array}$} \\
\hline $\begin{array}{l}\text { Orientation and area } \\
\text { of window }\end{array}$ & \multicolumn{4}{|c|}{$\begin{array}{l}\text { Orientation of window: Northwest } 15 \text { degrees } \\
\text { Window area: } 3.2 \mathrm{~m} \times 1.8 \mathrm{~m}=5.76 \mathrm{~m}^{2}\end{array}$} \\
\hline \multirow[t]{2}{*}{ Amount of fresh air } & \multicolumn{2}{|c|}{ Infiltration } & \multicolumn{2}{|c|}{$\begin{array}{l}\text { Amount of fresh air into room } \\
\left(25 \mathrm{~m}^{3} / \text { hour-person; Weekday 8:00 17:00) }\right.\end{array}$} \\
\hline & \multicolumn{2}{|c|}{0.5 times/hour } & \multicolumn{2}{|c|}{1.4 times/hour } \\
\hline \multirow{2}{*}{ Internal heat generation } & \multicolumn{2}{|c|}{$\begin{array}{c}\text { Body } \\
\text { (heat generation: } 108 \mathrm{~W} / \text { person) }\end{array}$} & $\begin{array}{c}\text { Lighting } \\
\text { (efficiency: 0.9) }\end{array}$ & $\begin{array}{l}\text { OA equipment } \\
\text { (Sensible heat) }\end{array}$ \\
\hline & \multicolumn{2}{|c|}{ Number of person: 36 person } & $10 \mathrm{~W} / \mathrm{m}^{2}$ & $5.8 \mathrm{~W} / \mathrm{m}^{2}$ \\
\hline Air conditioning service & \multicolumn{4}{|c|}{ Weekday 8:00 17:00 } \\
\hline \multirow{3}{*}{$\begin{array}{c}\text { Temperature and } \\
\text { Humidity } \\
\text { settings }\end{array}$} & & $\begin{array}{l}\text { Heating season } \\
\text { (Dec } \sim \text { Mar) }\end{array}$ & $\begin{array}{c}\text { Cooling season } \\
\text { (June } \sim \text { Sept })\end{array}$ & $\begin{array}{c}\text { Middle season } \\
\text { (April May; Oct } \sim \text { Nov) }\end{array}$ \\
\hline & Temperature $\left({ }^{\circ} \mathrm{C}\right)$ & 22 & 28 & 26 \\
\hline & \begin{tabular}{|c|} 
Humidity \\
$(\%)$
\end{tabular} & 40 & 60 & 50 \\
\hline
\end{tabular}

In this research, the software, New HASP/ACLD- $\beta$, is used to calculate the thermal loads of buildings. As EnergyPlus is used in U.S., New HASP/ACLD- $\beta$ is a simulation program often used to calculate 
the indoor temperature, humidity and thermal loads of buildings, which has been developed for the purpose of evaluating the energy consumption of air-conditioning in buildings [21]. Parameters in New HASP/ACLD- $\beta$ calculation program, such as the solar reflectivity of exterior walls, structure of building walls, operating condition of air conditioning, could be rewritten easily. To calculate the thermal loads of buildings by New HASP/ACLD- $\beta$, the following input data are needed for the calculation period.

- Hourly meteorological data: air temperature, absolute humidity, direct solar radiation, diffuse solar radiation, cloud cover, wind direction and wind speed, etc.

- Building data: the longitude, latitude of the building, wall dimensions and directions, roof and overhang dimensions, ground height, solar reflectivity of ground, solar radiation absorption and long-wave emissivity of outer walls, the structure and materials of outer and inner walls, ceiling height, distance to and height of neighboring buildings, and schedule of indoor activities and occupancy, etc.

For this study, monthly and annual thermal loads (annual cooling and heating loads) of subject school before and after construction of HR roofing sheet were calculated using New HASP/ACLD- $\beta$. Conditions of the thermal load calculations are shown in Table 2.

\section{Results and discussion}

Monthly and annual thermal loads (annual cooling and heating loads) before and after construction of the HR roofing sheet in the subject school were calculated and shown in Figure 3 and Figure 4, respectively.

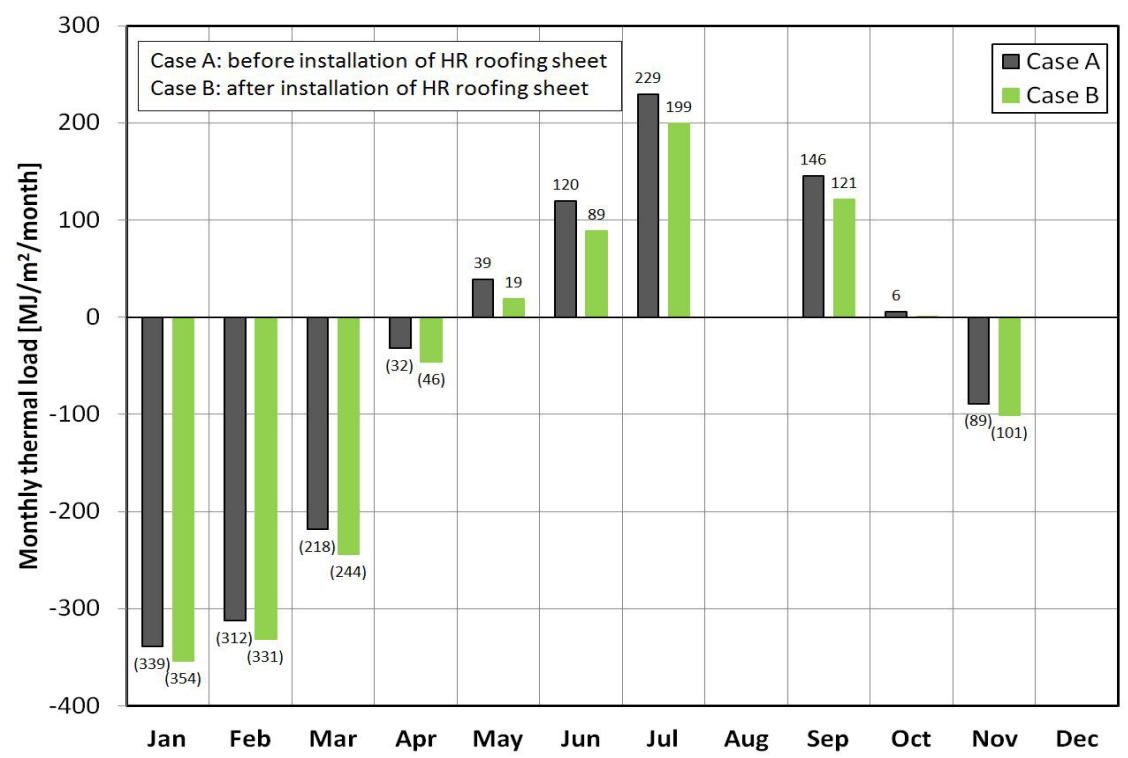

Figure 3. Monthly thermal load of subject school (Case A: before construction of HR roofing sheet; Case B: after construction of HR roofing sheet).

It showed that: i) the thermal load from May to October (here noted that September is summer vacation of school) decreased when the roof was covered with HR roofing sheet (Case B). Among these months, July has the largest reduction of monthly cooling load, about $30 \mathrm{MJ} / \mathrm{m}^{2}$-month; ii) compared to the case before the roof was retrofitted with HR roofing sheet (Case A), annual total thermal loads decreased about $25 \mathrm{MJ} / \mathrm{m}^{2}$-year and the cooling load decreased about $112 \mathrm{MJ} / \mathrm{m}^{2}$-year after the roof was constructed with the HR roofing sheet (Case B). However, annual heating load increased about $87 \mathrm{MJ} / \mathrm{m}^{2}$-year after construction of HR roofing sheet (Case B). 
The result indicated that the HR roofing sheet is more effective for cooling load in the summer period. However, it is disadvantage for heating load in the winter period.

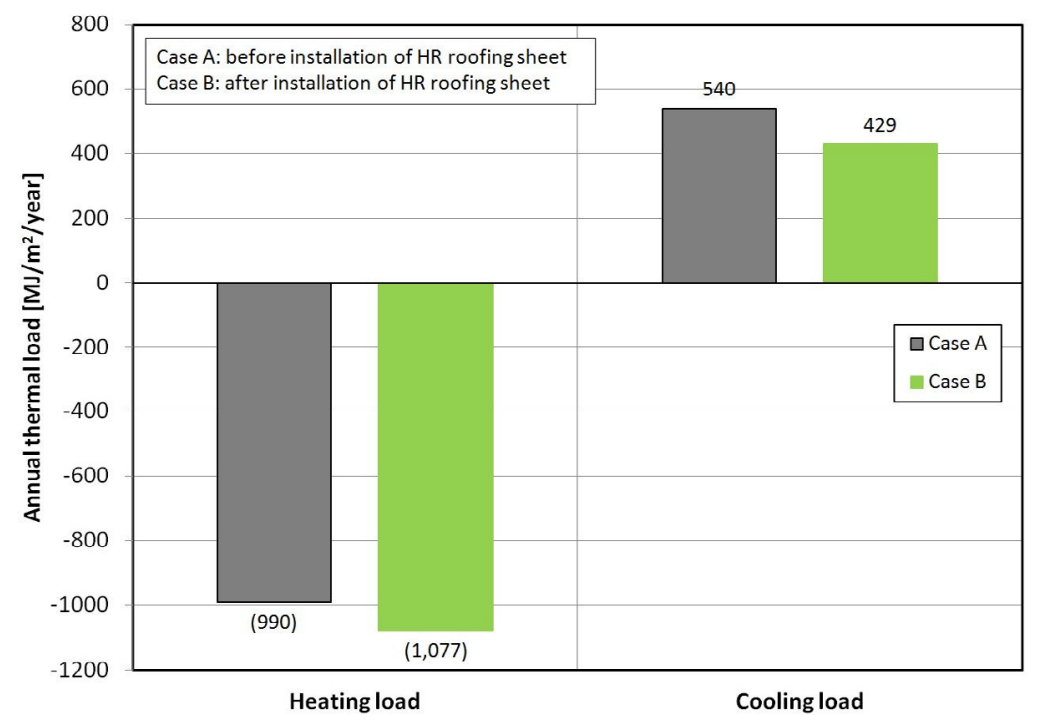

Figure 4. Annual cooling and heating loads of subject school (Case A: before construction of HR roofing sheet; Case B: after construction of HR roofing sheet).

\section{Refurbishment for reducing thermal loads}

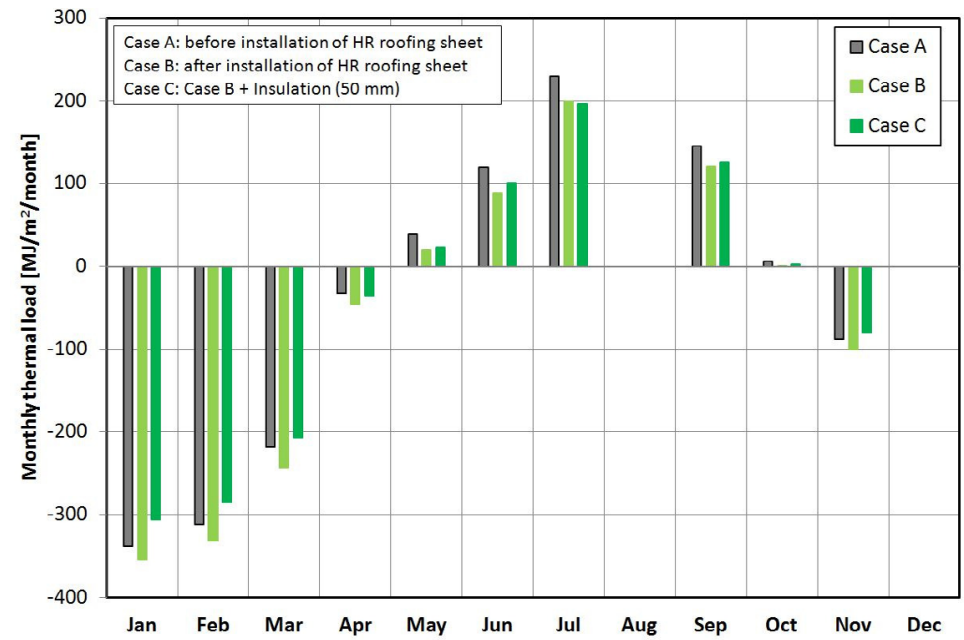

Figure 5. Monthly thermal load of subject school (Case A: before construction of HR roofing sheet; Case B: after construction of HR roofing sheet; Case C: Case B + Insulation thickness of $50 \mathrm{~mm}$ ).

In order to minimize the total thermal load and heating load, according to our previous study [22], this study considers adding thermal insulation with a thickness of $50 \mathrm{~mm}$ to the roof of the subject school combined with the HR roofing sheet (Case C).

Monthly and annual thermal loads (annual cooling and annual heating loads) under three cases (Case A; Case B; Case C) were calculated and shown in Figure 5 and Figure 6.

It showed that: i) the total thermal load decreased about $168 \mathrm{MJ} / \mathrm{m}^{2}$-year (cooling load decreased about $91 \mathrm{MJ} / \mathrm{m}^{2}$-year and heating load decreased about $77 \mathrm{MJ} / \mathrm{m}^{2}$-year) for Case C, compared to Case 
A; ii) the total thermal load decreased about $144 \mathrm{MJ} / \mathrm{m}^{2}$-year (cooling load increased about $20 \mathrm{MJ} / \mathrm{m}^{2}$ year and heating load decreased about $164 \mathrm{MJ} / \mathrm{m}^{2} /$-ear) for Case C, compared to Case B.

The result indicated that the appropriate combination of HR roofing sheet and thermal insulation of roof is more effective to reduce the annual thermal load, which is directly related to energy conservation of buildings, compared to HR roofing sheets alone or an added thermal insulation of the roof alone.

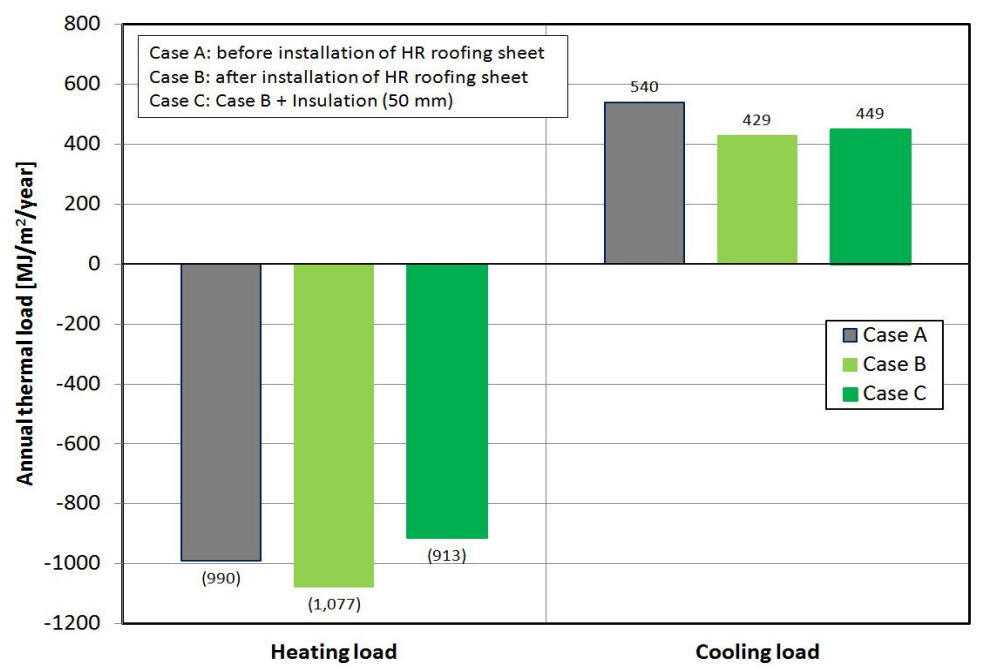

Figure 6. Annual thermal load of subject school (Case A: before construction of HR roofing sheet; Case B: after construction of HR roofing sheet; Case C: Case B + Insulation thickness of $50 \mathrm{~mm}$ ).

\section{Conclusions and future research}

The thermal load of subject school before and after construction of the HR roofing sheet was calculated using the software, New HASP/ACLD- $\beta$ in this study. For retrofitting the roof of the subject school to minimize the thermal load, thermal insulation of the roof with a thickness of $50 \mathrm{~mm}$ is considered to be added to the roof combined with the HR roofing sheet.

The cooling and the total thermal loads of subject school decreased after the construction of HR roofing sheet on the roof of subject school. However, the heating load increased after the construction of the HR roofing sheet. Thus, it is considered that the HR materials are effective in the summer and opposite in the winter.

For the location of Osaka $\left(34.7^{\circ} \mathrm{N}\right)$, if the thermal insulation could be considered be used together with the HR roofing sheet, it is sufficient to combine the insulation thickness of approximately $50 \mathrm{~mm}$ with the HR roof sheet (solar reflectivity was investigated to be about 0.50 ) to reduce the thermal load directly related to energy consumptions for the subject school.

In order to apply the HR materials more widely, due to the high-cost of current HR materials applied to roofs, the development of low-cost HR materials should be an important issue for the future research. In addition, if the HR material could be applied to building facades, the further work should focus on preventing the "light pollution" to the neighboring buildings, and the reflection directional characteristics of these HR materials should be studied.

\section{Acknowledgment}

The authors are sincerely grateful to the Foundation of Construction Materials Industrial Promotion Tostem Corporation, the Architecture Research Foundation of Takenaka Scholarship Foundation of Japan, and the Urban Studies of Osaka City University for their support. We are also grateful to the 
Department of Urban Development Department and Education Committee of Osaka for their support during measuring.

\section{References}

1. M. Santamouris, A. Synnefa, and T. Karlessi, Sol. Energy, 85 (12), 3085-3102 (2011)

2. I. Livada, M. Santamouris, K. Niachou, N. Papanikolaou, and G. Mihalakakou, J. Theor. Appl. Climatol., 71, 219-230 (2002)

3. P. Mihalakakou, H. Flokas, M. Santamouris, and C. Helmis, J. Appl. Meteorol,, 41, 519-527 (2002)

4. S. Hassid, M. Santamouris, N. Papanikolaou, A. Linardi, N. Klitsikas, C. Georgakis, and D. Assimakopoulos, Energy Build., 32, 131-141 (2000)

5. M . Santamouris, K. Paraponiaris, and G. Mihalakakou, Clim. Change, 80, 265-276 (2007)

6. H. Akbari, S. Konopacki, and M. Pomerantz, Energy, 24, 391-407 (1999)

7. A. L. Pisello, F. Cotana, and L. Brinchi, Energy Procedia, 45, 453-462 (2014)

8. M. Santamouris, Energy and climate in the Urban Built Environment (2001)

9. F. Rossi, B. Castellani, A. Presciutti, E. Morini, M. Filipponi, A. Nicolini, and M. Santamouris, Appl. Energy, 145, 8-20 (2015)

10. J. Yuan, K. Emura, and C. Farnham, J. Build. Phys., 38 (6), 500-516 (2014)

11. Y. Han, J. E. Taylor, and A. L. Pisello, Energy Build., 102, 380-389 (2015)

12. M. Dabaieh, O. Wanas, M. A. Hegazy, and E. Johansson, Energy Build., 89, 142-152 (2015)

13. Osaka District Meteorological Observatory, Ministry of the Environment Report: Research on the environmental impact of business considering the heat island phenomenon in 2002 (2003). Available at: http://www.jma.go.jp/jma/index.html

14. P. L. Luis, O. José, and P. Christine, Energy Build., 40 (3), 394-398 (2008)

15. Ministry of Land, Infrastructure and Transport and the Environment, The measurement report of heat island by anthropogenic heat suppression in 2012 (2013) (in Japanese)

16. T. Inoue, Build. Technol., 684, 142-145 (2007) (in Japanese)

17. M. Nishioka, S. Inoue, and K. Sakai, J. Environ. Eng., 73, 1249-1254 (2008) (in Japanese)

18. H. Sakai, K. Emura, N. Igawa, and H. Iyota, Proceedings of the Second International Conference on Countermeasures to Urban Heat Islands (SICCUHI), held September 21-23, in Berkeley, California, CD-ROM 211450, 1-6 (2009)

19. J. Yuan, C. Farnham, and K. Emura, Energy Build., 103, 107-117 (2015)

20. J. Yuan, K. Emura, and H. Sakai, J. Build. Phys., 37 (2), 170-184 (2012)

21. The Society of Heating, Air-Conditioning and Sanitary Engineers of Japan (SHASEJ), Operation Manual of New HASP / ACLD- $\beta$ (2004) (in Japanese)

22. J. Yuan, C. Farnham, K. Emura, and M. A Alam, Build. Environ., 103, 228-237 (2016) 